\title{
The role of torovirus in nosocomial viral gastroenteritis at a large tertiary pediatric centre
}

\author{
JB Gubbay MBBS FRCPC FRACP MMedSc ${ }^{1,2,3}$, A Al-Rezqi MD PhD FRCPC ${ }^{1}$, M Hawkes MD PhD FRCPC ${ }^{1}$, \\ L Williams Bsc ${ }^{1}$, SE Richardson MD PhD FRCPC ${ }^{2,3}$, A Matlow MD PhD FRCPC ${ }^{1}$
}

\begin{abstract}
JB Gubbay, A Al-Rezqi, M Hawkes, L Williams, SE Richardson, A Matlow. The role of torovirus in nosocomial viral gastroenteritis at a large tertiary pediatric centre. Can J Infect Dis Med Microbiol 2012;23(2):78-81.
\end{abstract}

OBJECTIVE: To describe the viral etiology and epidemiology of nosocomial viral gastroenteritis (NVG) at a tertiary care pediatric hospital and identify any changes over the past two decades.

METHODS: Retrospective review of all patients with laboratoryconfirmed NVG at The Hospital for Sick Children (Toronto, Ontario), from January 1, 2004, to December 31, 2005.

RESULTS: One hundred forty-two episodes of NVG were found among 133 patients, occurring in 0.48 of 100 admissions. The median age was two years; $42 \%$ were $<1$ year of age and $41 \%$ were immunocompromised. The most commonly detected pathogen was torovirus $(67 \%$ of episodes), followed by rotavirus (19\%) and adenovirus (9\%). Seventyfive cases $(53 \%)$ were epidemiologically linked in 32 separate clusters (median cluster size two, range two to four). The NVG rate fell from 0.63 of 100 to 0.22 of 100 admissions after March $2005(\mathrm{P}<0.001)$ when enhanced infection control precautions were instituted in response to an outbreak of vancomycin-resistant Enterococcus.

CONCLUSIONS: Torovirus remains the most commonly identified cause of NVG at The Hospital for Sick Children. Most NVG cases were epidemiologically linked, and a significant reduction in cases occurred after the institution of enhanced infection control practices following an outbreak of vancomycin-resistant Enterococcus. Improved education and surveillance for NVG should lead to further reduction in this problem.

\section{Le rôle du torovirus en cas de gastroentérite virale nosocomiale dans un grand centre de pédiatrie tertiaire}

\begin{abstract}
HISTORIQUE : Les chercheurs ont effectué la présente étude pour décrire l'étiologie virale et l'épidémiologie de la gastroentérite virale nosocomiale (GVN) dans un hôpital de pédiatrie tertiaire et déterminer les changements constatés depuis vingt ans.

MÉTHODOLOGIE : Analyse rétrospective de tous les patients ayant une GVN confirmée en laboratoire à The Hospital for Sick Children (HSC) de

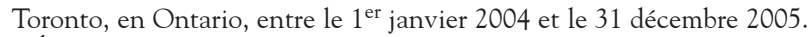
RÉSULTATS : Les chercheurs ont retracé 142 épisodes de GVN chez 133 patients, dans 0,48 pour 100 des admissions. Ils avaient un âge médian de deux ans, $42 \%$ avaient moins d'un an et $41 \%$ étaient immunocompromis. Le torovirus était le pathogène le plus décelé (67\% des épisodes), suivi du rotavirus (19\%) et de l'adénovirus (9\%). Soixante-quinze cas (53\%) étaient liés à 32 grappes distinctes (grappe médiane de deux, plage de deux à quatre) sur le plan épidémiologique. Le taux de GVN a fléchi de 0,63 à 0,22 pour 100 des admissions après le 5 mars $2005(\mathrm{P}<0,001)$, lorsqu'on a renforcé les précautions de contrôle des infections en réponse à une épidémie d'entérocoques résistant à la vancomycine (ERV).

CONCLUSIONS : Le torovirus demeure la principale cause de GVN diagnostiquées à l'HSC. La plupart des cas de GVN étaient liés sur le plan épidémiologique, et on a constaté une importante diminution du nombre de cas après le renforcement des pratiques de contrôle des infections découlant d'une éclosion d'ERV. Une meilleure éducation et une plus grande surveillance à l'égard du GVN devraient favoriser l'atténuation plus marquée de ce problème.
\end{abstract}

Key Words: Gastroenteritis; Nosocomial infections; Pediatrics; Rotavirus; Torovirus

G astrointestinal infections are the third most common nosocomial infection in children, accounting for up to $20 \%$ of nosocomial infections in pediatric facilities (1-3). In developed countries, rotavirus, astrovirus and adenovirus are the predominant pathogens found in most studies (4-7). In a prospective study (6) conducted in 1985 at The Hospital for Sick Children (HSC) in Toronto, Ontario, $4.5 \%$ of patients developed nosocomial diarrhea and $10 \%$ of their room contacts became infected, with rotavirus causing almost one-half of the episodes. A decade later, torovirus was the most commonly identified cause of viral gastroenteritis (35\% of 206 cases), including cases that were nosocomially acquired (99 of 135, 74\%) (8). More recently, in a study examining nurse staffing patterns and nosocomial viral gastroenteritis (NVG) (1997 to 1999), torovirus was again found to be the principal pathogen (9).

Because HSC is one of the few centres that actively tests for torovirus, the purpose of the present study was to document the current epidemiology of NVG at our tertiary care pediatric academic health sciences centre, and to identify viral agents and risk factors for acquisition. With the present comprehensive review, we were also interested in comparing our findings with those of previously published studies from our institution to document any change in epidemiology over the past two decades.

\section{METHODS}

HSC is a 300 -bed tertiary care pediatric institution. All cases of laboratory-confirmed NVG over a two-year period, from January 1, 2004, to December 31, 2005, were included in the present study. Case ascertainment was performed using the database of the Infection Prevention and Control program. Medical files of all cases were retrospectively reviewed. All NVG cases required laboratory confirmation in addition to clinical symptoms, characterized by two or more loose stools over a $24 \mathrm{~h}$ period beginning at least $48 \mathrm{~h}$ to $72 \mathrm{~h}$ after admission. Viruses were identified in stools by direct electron microscopy (EM) as previously described $(8,10)$. Stool samples from children $>1$ year of age were also tested for Clostridium difficile toxin using the Vero cell cytotoxicity assay (11).

The NVG rate was calculated as the number of cases of NVG per 1000 patient days or per 100 hospital admissions. An epidemiological

${ }^{1}$ Department of Paediatrics, The Hospital for Sick Children and University of Toronto; ${ }^{2}$ Department of Laboratory Medicine and Pathobiology,

University of Toronto; ${ }^{3}$ Division of Microbiology, Department of Paediatric Laboratory Medicine, The Hospital for Sick Children, Toronto, Ontario Dr Gubbay and Dr Al-Rezqi are co-first authors

Correspondence: Dr Jonathan B Gubbay, Division of Infectious Diseases, Department of Paediatrics, The Hospital for Sick Children,

555 University Avenue, Toronto, Ontario M5G 1X8. Telephone 416-235-6258, fax 416-235-6550, e-mail jonathan.gubbay@oahpp.ca 
TABLE 1

Patient characteristics for 142 episodes of nosocomial viral gastroenteritis in 133 children

\begin{tabular}{lc}
\hline Characteristic & NVG patients \\
\hline Age, median (range) $^{*}$ & 2 years (25 days to 17 years) \\
Male $^{*}$ & $74(56)$ \\
Immunocompromised $^{*}$ & $55(41)$ \\
Surgical/invasive procedures & $74(56)$ \\
Prior antibiotic therapy* & $118(89)$ \\
Diapered $^{*}$ & $90(68)$ \\
Enteral feeding $^{*}$ & $76(57)$ \\
Vomiting $^{\dagger}$ & $99(70)$ \\
Fever $^{\dagger}$ & $111(79)$ \\
Bloody diarrhea $^{\dagger}$ & $20(14)$ \\
Duration of diarrhea, days, median (range) $^{\dagger}$ & $6(1$ to 76$)$ \\
\hline
\end{tabular}

Data presented as $n$ (\%) unless otherwise indicated. *Expressed as a percentage of patients $(n=133) ;{ }^{\dagger}$ Expressed as a percentage of cases $(n=142)$

link was defined as a temporal and geographical association between patients. Temporal association was ascribed when one patient's diarrheal illness coincided with the onset of the next, within the incubation period of the virus (rotavirus, two to four days; adenovirus, three to 10 days; astrovirus, one to four days; norovirus, $12 \mathrm{~h}$ to $72 \mathrm{~h}$; torovirus, up to seven days) (12). A geographical association was considered to be present when cases occurred on the same hospital ward. A cluster was defined as two or more cases of NVG with an epidemiological link. An outbreak was defined as three or more cases of NVG of the same etiology on a given ward within a period of one month. Children with an underlying diagnosis of cancer, solid organ and hematopoietic stem cell transplantation were considered to be immunocompromised.

All demographic, clinical and laboratory data were entered into an Excel spread sheet (Microsoft Corporation, USA). Statistical analysis was conducted using SPSS (IBM Corporation, USA) and Epi Info Version 6 (Centers for Disease Control and Prevention, USA). Categorical data were compared using $\chi^{2}$ or Fisher's exact tests; continuous data were compared using the Student's $t$ test and medians were analyzed using the Wilcoxon rank sum test or Kruskall Wallis test, where appropriate. Trends in admission rate over time were analyzed month-wise using linear regression. Comparative statistics and CIs for NVG rates were computed assuming that rates followed a Poisson distribution. Data from two previous NVG studies conducted at HSC in 1985 and 1997 to 1999 that used the same laboratory methods $(6,9)$, were summarized and compared with the current study. The study was approved by the Research Ethics Board at HSC.

\section{RESULTS}

In the two years between January 1, 2004, and December 31, 2005, 142 episodes of microbiologically confirmed NVG were documented among 133 patients (Table 1). Seven patients had two episodes of NVG and one had three episodes. There was no difference in the prevalence of bloody diarrhea between immunocompromised and immunocompetent children. There was a trend toward longer duration of diarrhea in immunocompromised patients.

The NVG rate for the entire study period was 0.48 per 100 admissions (95\% CI 0.40 to 0.58 ) and 0.68 per 1000 patient days (95\% CI 0.57 to 0.80 ), and decreased over the study period $(\mathrm{P}<0.001)$. The NVG rate up until March 2005 was 0.63 per 100 admissions $(0.89$ per 1000 patient days), which fell significantly to 0.22 per 100 admissions (0.31 per 1000 patient days) after March $2005(\mathrm{P}<0.001)$ when enhanced infection control precautions were instituted following an outbreak of vancomycin-resistant Enterococcus (VRE) (Figure 1). Likewise, the rate of torovirus infection decreased markedly from 0.44 per 100 admissions ( 0.61 per 1000 patient days) through March 2005 to 0.11 per 100 admissions ( 0.15 per 1000 patient days) after March $2005(\mathrm{P}<0.001)$, whereas the rate of rotavirus infection was not significantly different during the two time periods $(\mathrm{P}=0.263)$.

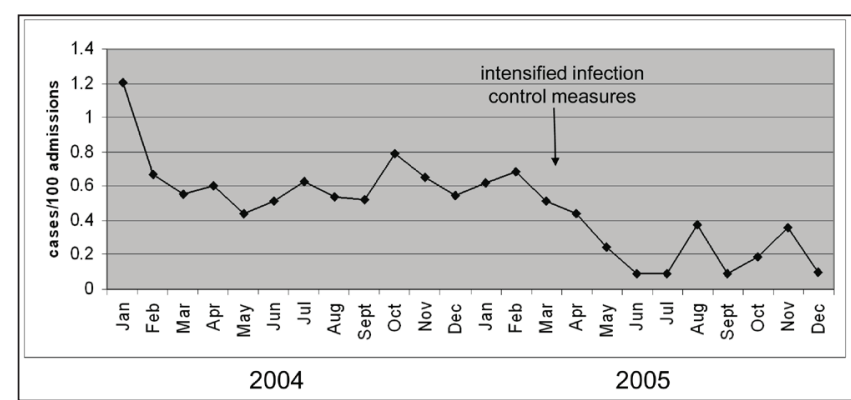

Figure 1) Rates of viral diarrhea decreased over the study period $(P<0.001)$, particularly after March 2005, when infection control measures were instituted due to a vancomycin-resistant Enterococcus outbreak

\section{TABLE 2}

Pathogens identified and nosocomial viral gastroenteritis (NVG) rates for two previous studies and the current study of NVG at The Hospital for Sick Children (Toronto, Ontario)

\begin{tabular}{|c|c|c|c|}
\hline \multirow[b]{2}{*}{ Characteristic } & \multicolumn{3}{|c|}{$\begin{array}{l}\text { Study period at The Hospital for Sick } \\
\text { Children* }\end{array}$} \\
\hline & $\begin{array}{l}1985^{\dagger} \\
(n=80)\end{array}$ & $\begin{array}{c}1997-1999^{\ddagger} \\
(n=43)\end{array}$ & $\begin{array}{c}2004-2005^{\S} \\
(n=142)\end{array}$ \\
\hline $\begin{array}{l}\text { Mean monthly rate } \\
\text { (per } 1000 \text { patient days) }\end{array}$ & 15.7 to 45.2 & 2.17 to 6.39 & 0.68 \\
\hline \multicolumn{4}{|l|}{ Virus identified } \\
\hline Torovirus & $0(0)$ & $23(53.5)$ & $95(67)$ \\
\hline Rotavirus & $33(43)$ & $10(23.3)$ & $27(19)$ \\
\hline Adenovirus & $6(8)$ & $3(7)$ & $13(9)$ \\
\hline Calicivirus/norovirus & $12(16)$ & $2(4.7)$ & $6(4.2)$ \\
\hline Astrovirus & $11(14)$ & $2(4.7)$ & $2(1.4)$ \\
\hline Other viral agents & $11(15)$ & $3(7)$ & $0(0)$ \\
\hline Salmonella species & $3(4)$ & & \\
\hline
\end{tabular}

Data presented as $n$ (\%) unless otherwise indicated. *In the 1985 study of NVG, a pathogen was identified in 95\% of cases of NVG; the 1997 to 1999 and the current (2004 to 2005) studies described microbiologically confirmed cases of NVG; ${ }^{\dagger}$ Reference $6 ;{ }^{\ddagger}$ Reference $9 ;{ }^{\S}$ Clostridium difficile was detected in 10 (15\%) of the 69 children >1 year of age tested for this pathogen

The most commonly identified pathogen was torovirus, detected in $95(67 \%)$ episodes, followed by rotavirus in $27(19 \%)$, adenovirus in $13(9 \%)$, norovirus in six $(4.2 \%)$ and astrovirus in two $(1.4 \%)$ of the episodes (Table 2). One patient had coinfection with torovirus and rotavirus, and six patients had two serial infections involving different viruses in each episode of NVG. Torovirus was the only virus identified in two patients with two and three NVG serial infections, respectively. Children with torovirus NVG were significantly older (median age three years, range one month to 17 years) than children with rotavirus NVG (median age six months, range three months to 13 years; $\mathrm{P}=0.013)$. Children with torovirus $\mathrm{NVG}$ were more likely to be immunocompromised (50\%) than those with rotavirus NVG (23\%; $\mathrm{P}=0.014)$. The prevalence of bloody diarrhea was similar in children with NVG due to torovirus (14\% with bloody diarrhea) and rotavirus ( $12 \%$ with bloody diarrhea). In children $>1$ year of age, $10(15 \%)$ of the 69 children that were tested were coinfected with toxin-producing $\mathrm{C}$ difficile (in six patients infected with torovirus, two with rotavirus, one with adenovirus and one with norovirus); six of the patients were immunocompromised. In total, 75 (53\%) of the cases were epidemiologically linked in 32 clusters (median cluster size two, range two to four). Ten outbreaks (eight torovirus, two adenovirus) of NVG involving 31 patients were detected during the study period. Rotavirus NVG was more common in winter (December 21 to March 21) with a rate of 0.21 per 100 admissions ( 0.3 per 1000 patient days); the rate was 0.07 per 100 admissions ( 0.10 per 1000 patient days) for all the other 
seasons combined $(\mathrm{P}<0.001)$. No significant seasonal differences were observed for rates of torovirus or adenovirus. Table 2 summarizes NVG rates and pathogens identified in the current and two previous studies of NVG conducted at HSC in 1985 and 1997 to 1999.

\section{DISCUSSION}

The present prospective surveillance study demonstrated that NVG remains a significant problem within our tertiary care pediatric centre. $(8,9)$. Torovirus was the major pathogen, occurring in all age groups and without seasonal predilection. In contrast, rotavirus NVG had a strong winter predominance and occurred more commonly in younger children. More than one-half of the cases of NVG reported in the present study had a clear epidemiological link, highlighting the potential for prevention with enhanced infection control practice. This is further underscored by the observed fall in NVG cases after March 2005, resulting from enhanced infection control precautions and awareness in response to a VRE outbreak in the hospital.

This is one of the largest studies of NVG in children reported in the literature to date, although the true numbers are likely even greater given that only laboratory confirmed (ie, EM) cases were included in the study. Earlier studies have identified rotavirus, astrovirus and adenovirus as the major pathogens in hospitalized children in developed countries (4-7). Bacterial causes of nosocomial gastroenteritis other than $\mathrm{C}$ difficile are rare $(13,14)$. In keeping with guidelines for testing patients with nosocomial gastroenteritis, we did not screen for bacterial enteric pathogens (15).

Langley et al (2) identified pathogens in 56\% of 217 nosocomial diarrhea episodes in children. Although most pathogens identified were viruses (38.3\% overall; rotavirus $17.5 \%$, adenovirus $16.6 \%$, other viruses $4.2 \%)$, C difficile was the most commonly identified single pathogen (18.0\% overall). EM was performed for part of the study by Langley et al (2), but torovirus was not reported. In a large study of gastroenteritis in children $<5$ years of age from Hong Kong (7), rotavirus was the cause of nosocomial gastroenteritis in $78.5 \%$ of 163 episodes. Unfortunately, it is difficult to compare studies of NVG because the methodologies and their respective sensitivities for detection of possible pathogens vary significantly.

Few institutions use EM for the diagnosis of viral gastroenteritis and, as a result, many still consider the role of torovirus as a cause of viral gastroenteritis dubious, despite immunomethodological confirmation in studies of both community- and hospital-acquired diarrhea (8,16-21). Although Koch's postulates have yet to be fulfilled for human torovirus, which cannot be cultured in vitro, animal research suggests gastrointestinal pathology results from torovirus infection. Studies of Breda virus, a torovirus infection in calves, show that these viruses infect differentiating epithelial cells in intestinal villi crypts, mostly in the large intestine $(22,23)$. Evidence of a host response to the virus in humans is supported by the demonstration of seroconversion to torovirus in $50 \%$ of children two years of age or younger and $66 \%$ of children older than two years of age in the 1995 to 1997 study at this institution (8). Duckmanton et al (24) were able to amplify a 219 nucleotide fragment of torovirus-like particles identified on EM examination of stools from children using primers designed from the $3^{\prime}$ end of the torovirus prototype, Berne virus. The nucleotide sequences were found to be $99 \%$ identical to Berne virus present in the same area, providing support to the observation that the particles seen on EM examination of stools were indeed toroviruses (24).

Testing for torovirus at HSC began in 1993 and, since then, torovirus has emerged as the principal cause of NVG at our institution. Torovirus accounted for $54 \%$ of laboratory-confirmed NVG at HSC during 1997 to 1999 , and increased to 67\% during 2004 to 2005 (9).

Torovirus has been associated with cases of necrotizing enterocolitis (25), and particles similar to toroviruses (coronavirus-like particles) have been described in an outbreak of gastrointestinal illness in a neonatal intensive care unit (26). Although these associations are interesting, there is no firm evidence to date to suggest that torovirus plays an etiological role in necrotizing enterocolitis.
Langley et al (2) reported a median age of 1.3 years in children with NVG, which is younger than that observed in the present study. In the 1985 study at HSC, the nosocomial diarrhea rate was $8.8 \%$ for children zero to 11 months of age, $3.6 \%$ for those 12 to 35 months of age, and $0.6 \%$ in those $\geq 36$ months of age (6). As was our observation, Jamieson et al (8) reported that children with torovirus infection were older than those with gastroenteritis caused by other viruses.

As reported in 1993 to 1995 at HSC, we have documented a high proportion of episodes of torovirus NVG in immunocompromised patients (Table 1). Prospective studies would help clarify whether previous antibiotic use or surgery are risk factors for NVG (Table 1). We also noted a similar prevalence of bloody diarrhea in torovirus infected patients to that reported by Jamieson et al (8) (Table 1). Consistent with other studies, we found that $\mathrm{C}$ difficile was present in $14 \%$ of the stools of patients with NVG, representing either coinfection or asymptomatic carriage of either potential pathogen $(8,27)$. The reason for the high prevalence of $\mathrm{C}$ difficile in the present study may be related to frequent antibiotic use, a known risk factor for $\mathrm{C}$ difficile infection.

The NVG rate in the persent study was markedly lower than that documented in previous studies of NVG at HSC (Table 2). Possible reasons for the falling rate of NVG include enhanced infection control education and practice, an increase in single patient rooms to $85 \%$ of all rooms following renovations in 1992, and an increased investment in employing infection control practitioners and improving staff education with regard to the importance of infection control practices. This education resulted in an increased awareness of the need for hand hygiene, improved contact precautions through use of personal protective equipment, and awareness for staff to stay home when unwell with acute gastrointestinal or respiratory symptoms. Recent recommendations of the American Institute of Architects underscore the importance of single-bed rooms to reduce the rate of nosocomial infections (28). This is of particular importance in pediatric institutions given that so many children are diapered or are too developmently challenged to effect adequate toilet hygiene. We postulate that the reduction in NVG after March 2005 was an indirect result of the enhanced infection control practice in response to a VRE outbreak. Stegenga et al (9) documented a relationship between nurse understaffing and increased incidence of NVG at HSC from 1997 to 1999 . This could be explained by the fact that basic but essential infection control practices, such as hand hygiene, are compromised when nursing understaffing occurs.

The present large study of NVG at a tertiary care pediatric institution highlights the continuing significance of the problem and has provided some insights into the epidemiology of NVG over the past 20 years. We have demonstrated that torovirus continues to be the major pathogen at HSC in all studies of NVG since 1993, despite the fact it is rarely reported from other institutions. Our success in diagnosing torovirus is directly related to the integral role EM plays in our diagnostic virology laboratory. Development of a molecular test for human torovirus would provide an identification method that could be used in other centres to further understand its epidemiology and role in human infection. The present study has also documented the dramatic reduction in NVG over the past 20 years at HSC, which is most likely a direct result of the evolution of infection control as a discipline in health care. With institution of infection control practice in hospitals has come greater emphasis on isolation, contact precautions, the importance of hand hygiene and an increase in singlebed rooms. Opportunities for improvement still remain. Ongoing education, surveillance and a focus on the role of the environment as a reservoir for transmissible pathogens should further reduce this problem.

DISCLAIMER: This study was conducted without financial support.

DISCLOSURE: The authors have no conflicts of interest to report. 


\section{REFERENCES}

1. Welliver RC, McLaughlin S. Unique epidemiology of nosocomial infections in a children's hospital. Am J Dis Child $1984 ; 138: 131-5$

2. Langley JM, LeBlanc JC, Hanakowski M, Goloubeva O. The role of Clostridium difficile and viruses as causes of nosocomial diarrhea in children. Infect Control Hosp Epidemiol 2002;23:660-4.

3. Roy TE, McDonald S, Patrick ML, et al. A survey of hospital infection in a pediatric hospital. Can Med Assoc J 1962;87:531-8.

4. Shastri S, Doane AM, Gonzales J, Upadhyayula U, Bass DM. Prevalence of astrovirus in a children's hospital. J Clin Microbiol 1998;36:2571-4.

5. Bennet R, Hedlund KO, Ehrnst A, Eriksson M. Nosocomial gastroenteritis in two infant wards over 26 months. Acta Paediatr 1995;84:667-71.

6. Ford-Jones EL, Mindorff CM, Gold R, Petric M. The incidence of viral-associated diarrhea after admission to a pediatric hospital. Am J Epidemiol 1990;131:711-8.

7. Lam BC, Tam J, Ng MH, Yeung CY. Nosocomial gastroenteritis in paediatric patients. J Hosp Infect 1989;14:351-5.

8. Jamieson FB, Wang EE, Bain C, Good J, Duckmanton L, Petric M. Human torovirus: A new nosocomial gastrointestinal pathogen. J Infect Dis 1998;178:1263-9.

9. Stegenga J, Bell E, Matlow A. The role of nurse understaffing in nosocomial viral gastrointestinal infections on a general pediatrics ward. Infect Control Hosp Epidemiol 2002;23:133-6.

10. Petric M, Tellier R. Rotaviruses, caliciviruses, astroviruses, and other diarrheic viruses. In: Murray PR, Baron EJ, Jorgensen JH, Pfaller MA, Yolken RH, eds. Manual of Clinical Microbiology, 8th edn. Washington, DC: ASM Press, 2003:1439-51.

11. Qualman SJ, Petric M, Karmali MA, Smith CR, Hamilton SR. Clostridium difficile invasion and toxin circulation in fatal pediatric pseudomembranous colitis. Am J Clin Pathol 1990;94:410-6.

12. Red Book. Report of the Committee on Infectious Diseases, 27 edn. American Academy of Pediatrics; 2006.

13. Lopman BA, Reacher MH, Vipond IB, et al. Epidemiology and cost of nosocomial gastroenteritis, Avon, England, 2002-2003. Emerg Infect Dis 2004;10:1827-34.

14. Moreira LL, Netto EM, Nascimento-Carvalho CM. Nosocomial gastroenteritis in children with and without rotavirus infection. Pediatr Infects Dis J 2009;28:72.

15. Fecal and Other Gastrointestinal Cultures and Toxin Assays. In: Isenberg HD, ed. Clinical Microbiology Procedures Handbook, 2nd edn. American Society of Microbiology Press, 2004:3.8.1.4.
16. Weiss M, Steck F, Horzinek MC. Purification and partial characterization of a new enveloped RNA virus (Berne virus). J Gen Virol 1983;64:1849-58.

17. Horzinek MC, Flewett TH, Saif LJ, Spaan WJ, Weiss M, Woode GN. A new family of vertebrate viruses: Toroviridae. Intervirology 1987;27:17-24.

18. Durham PJK, Hassard LE, Norman GR, Yemen RL. Viruses and virus-like particles detected during examination of feces from calves and piglets with diarrhea. Can Vet J 1989;30:876-81.

19. Duckmanton L, Carman S, Nagy E, Petric M. Detection of bovine torovirus in fecal specimens of calves with diarrhea from Ontario farms. J Clin Microbiol 1998;36:1266-70.

20. Beards GM, Hall C, Green J, Flewett TH, Lamouliatte F, Du Pasquier P. An enveloped virus in stools of children and adults with gastroenteritis that resembles the Breda virus of calves. Lancet 1984;12:1050-2.

21. Beards GM, Brown DW, Green J, Flewett TH. Preliminary characterisation of torovirus-like particles of humans: Comparison with Berne virus of horses and Breda virus of calves. J Med Virol 1986;20:67-78.

22. Woode GN, Saif LJ, Quesada M, Winand NJ, Pholenz JF, Gourley NK. Studies with an unclassified virus isolated from diarreheal calves. Vet Microbiol 1985;7:221-40.

23. Woode GN, Saif LJ, Quesanda M, Winand NJ, Pohlenz JF, Gourley NK. Comparative studies on three isolates of Breda virus of calves. Am J Vet Res 1985;46:1003-10.

24. Duckmanton L, Luan B, Devenish J, Tellier R, Petric M. Characterization of torovirus from human fecal specimens. Virology 1997;239:158-68.

25. Lodha A, de Silva N, Petric M, Moore AM. Human torovirus: A new virus associated with neonatal necrotizing enterocolitis. Acta Paediatrica 2005;94:1085-8.

26. Vaucher YE, Ray CG, Minnich LL, Payne CM, Beck D, Lowe P. Pleomorphic, enveloped, virus-like particles associated with gastroenteritis illness in neonates. J Infect Dis 1981;145:27-36.

27. Ford-Jones EL, Mindorff CM, Langley JM, et al. Epidemiologic study of 4,864 hospital-acquired infections in pediatric patients. Pediatr Infect Dis J 1989;8:668-75.

28. Guidelines for Design and Construction of Health Care Facilities. American Institute of Architects, 2006. 


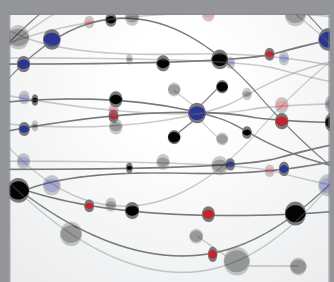

The Scientific World Journal
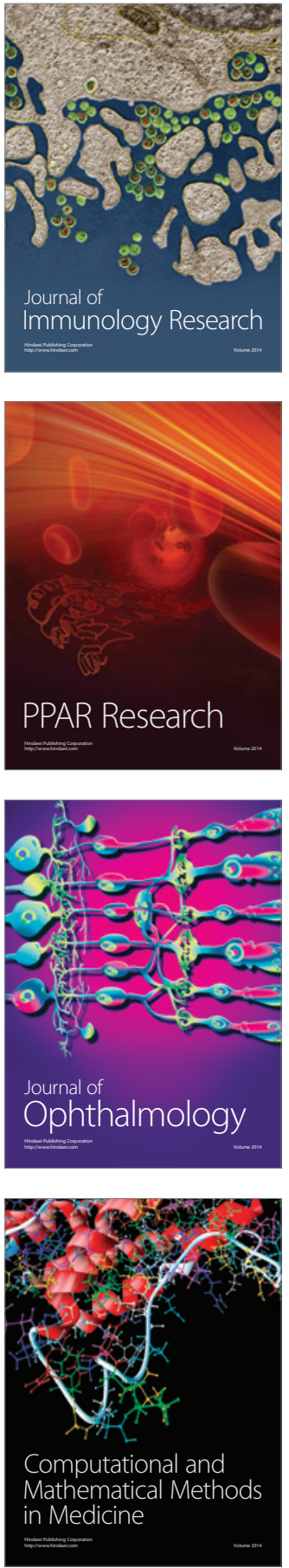

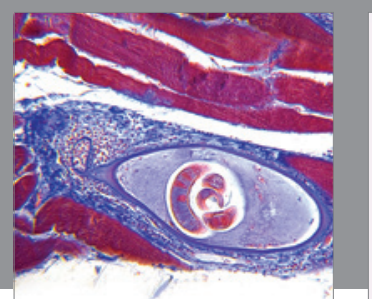

Gastroenterology Research and Practice

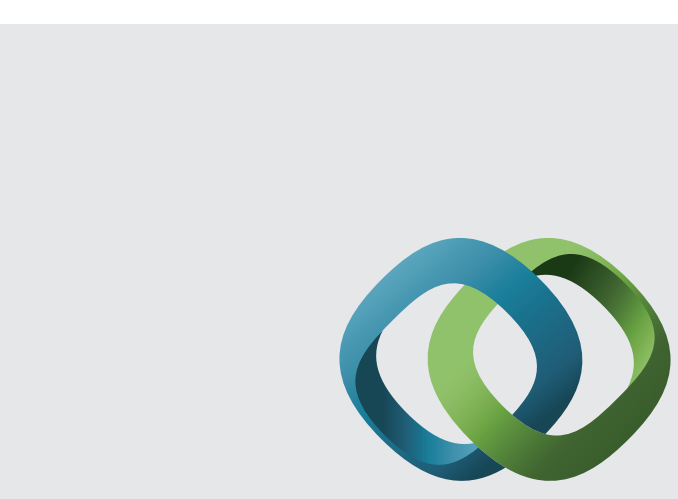

\section{Hindawi}

Submit your manuscripts at

http://www.hindawi.com
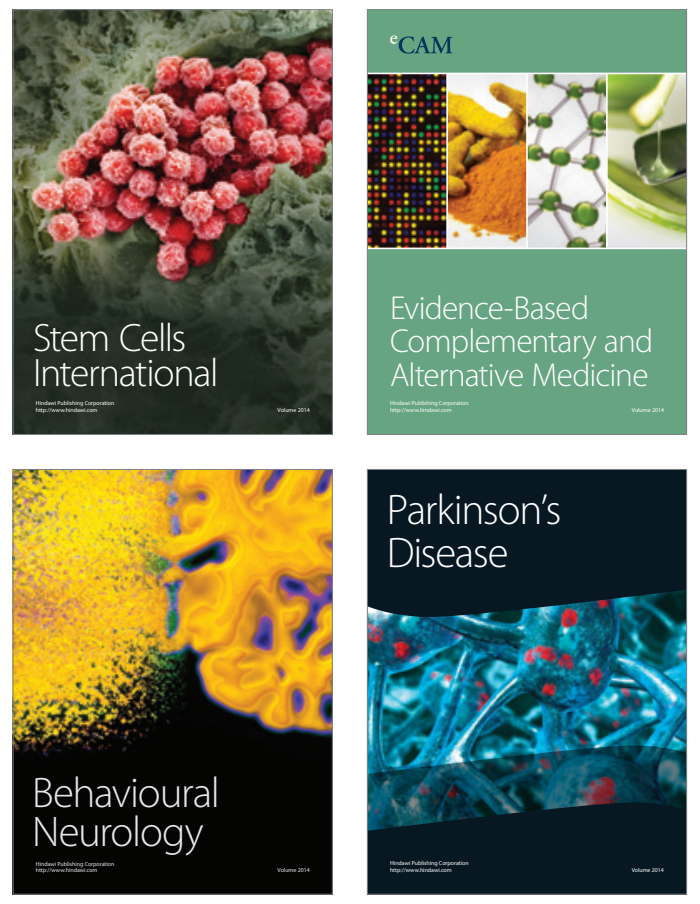
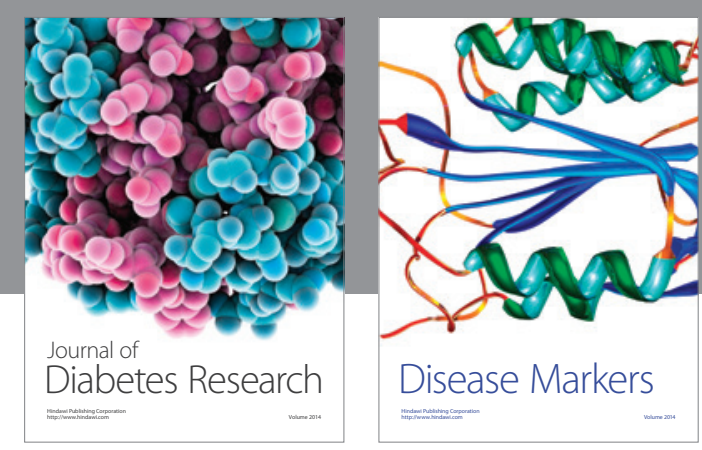

Disease Markers
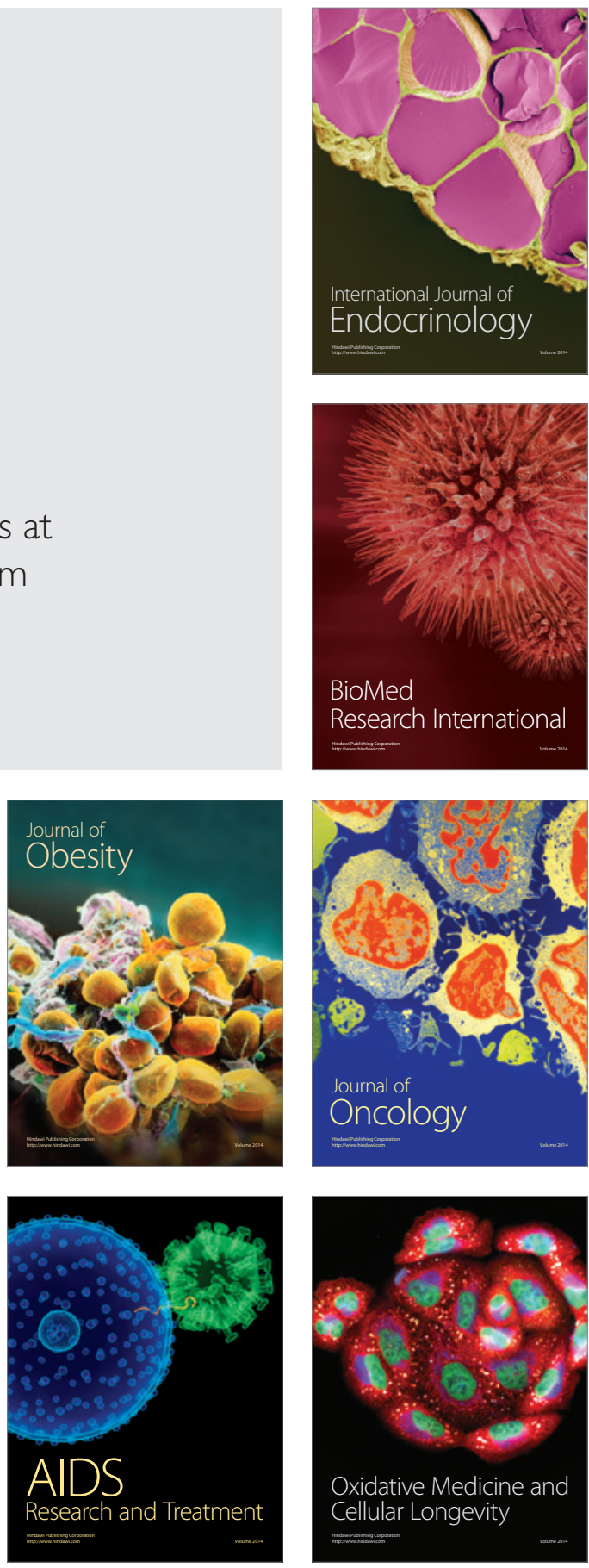